\title{
Electrolyzed-reduced water inhibits acute ethanol-induced hangovers in Sprague-Dawley rats
}

\author{
Seung-Kyu Park ${ }^{1}$, Xu-Feng QI ${ }^{1}$, Soon-Bong Song ${ }^{1}$, Dong-Heui KIm ${ }^{1}$, Yung-Chien Teng ${ }^{1}$, Yang-Suk Yoon ${ }^{1}$, \\ Kwang-Yong KIM ${ }^{2}$, Jian-Hong $\mathrm{LI}^{3}$, Dan $\mathrm{JIN}^{4}$ and Kyu-Jae LEE ${ }^{1,2}$ \\ ${ }^{1}$ Department of Environmental Medical Biology, ${ }^{2}$ Institute of Basic Medical Science, Wonju College of Medicine, Yonsei University, \\ Wonju, Gangwon, 220-701, Republic of Korea; ${ }^{3}$ College of Plant Science and Technology, Huazhong Agricultural University, Wuhan, \\ Hubei 430070, China; and ${ }^{4}$ Department of Immunology and Pathogenic Biology, College of Medicine, Yanbian University, Yanji, Jilin, \\ 133000, China
}

(Received 18 June 2009; and accepted 6 July 2009)

\begin{abstract}
Ethanol consumption disturbs the balance between the pro- and anti-oxidant systems of the organism, leading to oxidative stress. Electrolyzed-reduced water (ERW) is widely used by people in East Asia for drinking purposes because of its therapeutic properties including scavenging effect of reactive oxygen species. This study was performed to investigate the effect of ERW on acute ethanol-induced hangovers in Sprague-Dawley rats. Alcohol concentration in serum of ERWtreated rats showed significant difference at $1 \mathrm{~h}, 3 \mathrm{~h}$ and $5 \mathrm{~h}$ respectively as compared with the rats treated with distilled water. Both alcohol dehydrogenase type 1 and acetaldehyde dehydrogenase related with oxidation of alcohol were significantly increased in liver tissue while the level of aspartate aminotransferase and alanine aminotransferase in serum was markedly decreased $24 \mathrm{~h}$ after pre-oral administration of ERW. Moreover, oral administration of ERW significantly activated non-ezymatic (glutathione) and enzymatic (glutathione peroxidase, glutathione-S-transferase, $\mathrm{Cu} / \mathrm{Zn}$-superoxide dismutase and catalase) antioxidants in liver tissues compared with the control group. These results suggest that drinking ERW has an effect of alcohol detoxification by antioxidant mechanism and has potentiality for relief of ethanol-induced hangover symptoms.
\end{abstract}

Large quantities of ethanol consumption leads to liver damage, pancreatitis, myocardial infarction and neuropathy and exacerbates the symptoms of tuberculosis and other diseases (15). Ethanol consumption and associated medical disorders continue to grow in most western countries $(12,15)$. Heavy drink of ethanol induces increased serum ethanol concentration and levels of liver marker enzymes such as alanine aminotransferase (ALT), aspartate

Address correspondence to: Kyu-Jae Lee and Xu-Feng Qi, Department of Environmental Medical Biology, Wonju College of Medicine, Yonsei University, Wonju, 220-701, Republic of Korea

Tel: +82-33-741-0331, Fax: +82-33-731-6953

E-mail: medbio@yonsei.ac.kr (Kyu-Jae Lee); qixufeng117@hotmail.com (Xu-Feng Qi) aminotransferase (AST), alkaline phosphatase (ALP), and gamma glutamyl transferase (GGT) $(1,16,18)$. Moreover, ethanol administration causes more damage to the liver than to any other organ (14). The activities of antioxidants, such as reduced glutathione $(\mathrm{GSH})$, superoxide dismutase (SOD), catalase (CAT), glutathione peroxidase (GPx), or glutathioneS-transferase (GST), were greatly decreased in ethanol-treated mice or rats $(3,13,16,18)$. Therefore, the efficient detoxification of ethanol is crucial for the preservation of proper liver function as well as relief from ethanol-induced hangover.

Upon consumption, ethanol is rapidly oxidized in liver tissue to acetaldehyde and acetate by alcohol dehydrogenase $(\mathrm{ADH})$ and acetaldehyde dehydrogenase $(\mathrm{ALDH})$, respectively $(4,14)$. Furthermore, ethanol consumption disturbs the balance between 
the pro- and anti-oxidant systems of the organism, thereby leading to oxidative stress by generating free radicals or reactive oxygen species (ROS) (18), which results in liver injury. To scavenge these oxidants, cells possess an antioxidant system including non-enzymatic (GSH) and enzymatic (SOD, CAT, GPx and GST) antioxidants.

Electrolyzed-reduced water (ERW), generated by electrolysis of water, has been shown to exert a suppressive effect on the free radical level in living organisms, thereby resulting in disease prevention (6). Various biological effects of ERW have been reported such as anti-diabetic effect $(9,10)$, antioxidant effect (6), DNA protecting effect from oxidative damage by ROS (19), growth-stimulating effect of fetus (24), and growth-stimulating effect of anaerobic microflora in the human intestine (23). Huang et al. (8) demonstrated the potential therapeutic effects of ERW on end-stage renal disease patients, in whom the combined use of ERW during hemodialysis caused a reduction in oxidative stress. Although a variety of bioactive functions have been reported, the effect of ERW on alcoholic disorders in vivo is still unknown. Therefore, we performed a study to examine the effects of ERW on acute ethanolinduced hangover in Sprague-Dawley rats.

\section{MATERIALS AND METHODS}

Animals and experimental design. Male SpragueDawley rats (8 weeks, $350 \pm 20 \mathrm{~g}$ ) purchased from Orient Bio Inc. (Seongnam, Korea) were housed in stainless steel cages in a controlled environment of a $12 \mathrm{~h}$ light and dark cycle, $55 \pm 5 \%$ humidity and $22 \pm 2^{\circ} \mathrm{C}$. After 1 week of acclimatization, the rats were randomly assigned to control (Con, $\mathrm{n}=10)$ and experimental $(\mathrm{Exp}, \mathrm{n}=10)$ groups. After fasting for $12 \mathrm{~h}$, the Exp and Con groups were given electrolyzed-reduced water (ERW; $10 \mathrm{~mL} / \mathrm{kg}$ b.w.) and distilled water (DW) $(10 \mathrm{~mL} / \mathrm{kg}$ b.w.) respectively by gavage. After $30 \mathrm{~min}, 40 \%$ ethanol ( $5 \mathrm{~g} / \mathrm{kg}$ b.w.) was given to each rat by gavage, neither food nor water was supplied for $5 \mathrm{~h}$. Blood sample was taken from the tail vein of each rat after $1 \mathrm{~h}, 3 \mathrm{~h}$, and $5 \mathrm{~h}$, respectively for alcohol concentration assay, and from the retro-orbital plexus after $24 \mathrm{~h}$ for detection of liver marker enzymes: alanine aminotransferase (ALT), aspartate aminotransferase (AST), alkaline phosphatase (ALP), and gamma glutamyl transpeptidase (GGT). The blood samples were centrifuged at $3000 \times \mathrm{g}$ for $10 \mathrm{~min}$ at $4^{\circ} \mathrm{C}$. Liver tissues were separated from each rat of the Exp and Con groups after anesthesia with ether and liver perfusion for detec- tion of alcohol dehydrogenase (ADH), acetaldehyde dehydrogenase (ALDH), $\mathrm{Cu} / \mathrm{Zn}$-superoxide dismutase $(\mathrm{Cu} / \mathrm{Zn}-\mathrm{SOD})$ and catalase (CAT), reduced glutathione (GSH), glutathione peroxidase (GPx), and glutathione S-transferase (GST) $24 \mathrm{~h}$ after oraltreatment of ethanol. The animal use and care protocols for these experiments were approved by Yonsei University at Wonju Campus IACUC, Gangwon, Korea.

Preparation of electrolyzed-reduced water. ERW was generated from tap water using a continuously electrolyzing apparatus (DOD-003; HDr, Inc., Korea). The ERW used in this study has the following physical properties: $\mathrm{pH} 10.05 \pm 0.05$, oxidation reduction potential (ORP) of $-395.0 \pm 16.5 \mathrm{mV}$, dissolved oxygen (DO) of $4.82 \pm 0.11 \mathrm{mg} / \mathrm{L}$, and electrical conductivity (EC) of $223 \pm 5.5 \mu \mathrm{S}$.

Alcohol concentration assay in serum. The serum alcohol concentration was measured using an ethanol assay kit (BioVision, Mountain View, CA) according to the manufacturer's instructions. Briefly, $50 \mu \mathrm{L}$ of diluted standard or sample was incubated with reaction mix ( $46 \mu \mathrm{L}$ assay buffer, $2 \mu \mathrm{L}$ ethanol probe, and $2 \mu \mathrm{L}$ ethanol enzyme mixture) at room temperature for $60 \mathrm{~min}$, protected from light. Alcohol oxidase oxidized ethanol to generate $\mathrm{H}_{2} \mathrm{O}_{2}$ that reacts with ethanol probe to generate a colored product which can easily be quantified by colorimetric detection. The absorbance at $570 \mathrm{~nm}$ was detected with an automated microplate reader (Beckman Coulter, Fullerton, CA). The serum ethanol concentrations of the test samples were calculated from the standard curve, multiplied by the dilution factor.

Estimation of liver marker enzyme levels. Twenty four hours after treatment with ethanol, the serum levels of ALT, AST, ALP, and GGT were determined enzymatically using the FUJI DRI-CHEM 3500i (Fuji Photo Film Co., Tokyo, Japan), and expressed in $\mathrm{U} / \mathrm{L}$.

Reduced glutathione (GSH) concentration assay. The GSH concentration in liver tissue was measured using a glutathione assay kit (Cayman Chemical Company, Michigan, USA) according to the manufacturer's instructions. Briefly, samples were prepared at appropriate dilutions using MES buffer $(0.4 \mathrm{M}$ 2-(N-morpholino) ethanesulphonic acid, $0.1 \mathrm{M}$ phosphate, and $2 \mathrm{mM}$ EDTA, $\mathrm{pH} 6.0$ ). Then, $50 \mu \mathrm{L}$ of diluted samples and standards were incubated with $150 \mu \mathrm{L}$ assay cocktail [MES buffer $(11.25 \mathrm{~mL})$, 
reconstituted cofactor mixture $(0.45 \mathrm{~mL})$, enzyme mixture $(2.1 \mathrm{~mL})$, HPLC grade water $(2.3 \mathrm{~mL})$, and reconstituted 5,5'-Dithiobis (2-nitrobenzoic acid) $(0.45 \mathrm{~mL})]$ in the dark on an orbital shaker. The absorbance at $405 \mathrm{~nm}$ was measured using an automated microplate reader (Beckman Coulter) at $25 \mathrm{~min}$. The GSH concentrations of the samples were calculated from the standard curve.

Glutathione peroxidase (GPx) activity assay. The GPx activity of liver tissue was measured using a glutathione peroxidase assay kit (Cayman Chemical Company) according to the manufacturer's instructions. In brief, samples were prepared at appropriate dilutions using sample buffer $(50 \mathrm{mM}$ Tris- $\mathrm{HCl}$, $5 \mathrm{mM}$ EDTA, and $1 \mathrm{mg} / \mathrm{mL}$ BSA, $\mathrm{pH}$ 7.6). The reaction between samples and co-substrate mixture (which consists of NADPH, glutathione, and glutathione reductase) was initiated by cumene hydroperoxide. The absorbance at $340 \mathrm{~nm}$ was measured at least 5 times using an automated microplate reader (Beckman Coulter) at one minute intervals. The GPx activity was calculated using the following formula:

GST activity $(\mathrm{nmol} / \mathrm{min} / \mathrm{mL})=$ $\frac{\Delta \mathrm{A} 340 / \mathrm{min} .}{0.00373 / \mu \mathrm{M}} \times \frac{0.19 \mathrm{~mL}}{0.02 \mathrm{~mL}} \times$ sample dilution.

Glutathione S-Transferase (GST) activity assay. The GST activity of liver tissue was measured using a glutathione S-Transferase assay kit (Cayman Chemical Company) according to the manufacturer's instructions. Briefly, samples were prepared at appropriate dilutions using sample buffer $(100 \mathrm{mM}$ potassium phosphate, $0.1 \%$ triton $\mathrm{X}-100,1 \mathrm{mM}$ glutathione, and $1 \mathrm{mg} / \mathrm{mL}$ BSA, $\mathrm{pH} 6.5$ ). The reaction between samples and glutathione was initiated by adding 1-chloro-2, 4-dinitrobenzene (CDNB). The absorbance at $340 \mathrm{~nm}$ was measured at least 5 times using an automated microplate reader at one minute intervals. GST activity was calculated using the following formula:

GST activity $(\mathrm{nmol} / \mathrm{min} / \mathrm{mL})=$ $\frac{\Delta \mathrm{A} 340 / \mathrm{min} .}{0.00503 / \mu \mathrm{M}} \times \frac{0.2 \mathrm{~mL}}{0.02 \mathrm{~mL}} \times$ sample dilution.

Real time-PCR analysis. To detect ADH1, ALDH, $\mathrm{Cu} / \mathrm{Zn}-\mathrm{SOD}$ and CAT one gram of liver was homogenized with $5 \mathrm{~mL}$ of cold homogenization solu- tion (100 $\mathrm{mM}$ potassium phosphate, $2 \mathrm{mM}$ EDTA, $\mathrm{pH}$ 7.0) by a homogenizer (MICCRA D-1; ARTmoderne Labortechnik e.K., Germany). The homogenates were centrifuged at $10,000 \times g$ for $15 \mathrm{~min}$ at $4^{\circ} \mathrm{C}$, and the supernatants were removed for evaluation and stored at $-80^{\circ} \mathrm{C}$ until use. Total RNA was isolated from liver tissue using the TRI reagent (Molecular Research Center Inc., Cincinnati, USA). The quantity and purity of RNA were verified by measuring A260 and A280. cDNA was synthesized from total RNA $(2 \mu \mathrm{g})$ and oligo (dT)18 primers $(0.5 \mu \mathrm{g})$ using Prime RT premix (GeNet Bio, Korea) according to the manufacturer's instructions. cDNA was added to QuantiTect SYBR green PCR master mix (Qiagen $\mathrm{GmbH}$, Germany) and was then subjected to quantitative real-time PCR analysis using Rotor-Gene ${ }^{\text {TM }} 3000$ (Corbett Life Science). The primers used in this study are as follows: $\mathrm{ADH} 1$ (forward) 5'-CTG TAA AGC AGC AGG AGC AG-3', (reverse) 5'- TCC TAC GAC GAC GCT TAC AC-3'; ALDH (forward) 5'-GAT CAA CAC AGG TTG GCA AG-3', (reverse) 5'-TGA GGG CCT TGA TTT ATT CC-3'; Cu/Zn SOD (forward) 5'-ACC AGT GCA GGA CCT CAT TTT AA-3', (reverse) 5'-TCT CCA ACA TGC CTC TCT TCA TC-3'; CAT (forward) 5'-ACC AGG GCA TCA AAA ACT TG-3', (reverse) 5'-GCC CTG AAG CTT TTT GTC AG-3'; and $\beta$-actin (forward) 5'-TCA CCC ACA CTG TGC CCA TCT ACG A-3', (reverse) 5'-GGA TGC CAC AGG ATT CCA TAC CCA-3'. $\beta$-actin was used as an internal control. After a $10 \mathrm{~min}$ denaturation at $95^{\circ} \mathrm{C}$, the reactions were cycled for 45 cycles at $95^{\circ} \mathrm{C}$ for $30 \mathrm{~s}$ and at $60^{\circ} \mathrm{C}$ for $1 \mathrm{~min}$. To verify that only the specific product was amplified, a melting point analysis was done after the last cycle by cooling samples to $55^{\circ} \mathrm{C}$ and then increasing the temperature to $95^{\circ} \mathrm{C}$ at $0.2^{\circ} \mathrm{C} / \mathrm{s}$. Results were calculated using the $\Delta \mathrm{Ct}$ method normalizing to $\beta$-actin expression for each sample.

Statistical analysis. All data are presented as mean $\pm \mathrm{SD}(\mathrm{n}=10)$. Comparisons between two groups were analyzed by using the Student's $t$ test. A $P$ value less than 0.05 was considered to be statistically significant.

\section{RESULTS}

\section{Ethanol concentration in serum}

To examine the effect of ERW on acute ethanol-induced hangovers, the serum ethanol concentration of rat was measured at 1,3 , and $5 \mathrm{~h}$ after oral admin- 
istration of $40 \%$ ethanol. As shown in Table 1, the alcohol concentration of the control (Con) and the experimental (Exp) groups peaked at $1 \mathrm{~h}$ and decreased at $3 \mathrm{~h}$ and $5 \mathrm{~h}$ in order. The ethanol concentration of the Exp group treated with ERW was significantly reduced at $1 \mathrm{~h}(P<0.05), 3 \mathrm{~h}(P<0.05)$ and especially $5 \mathrm{~h}(P<0.01)$ compared with that of the Con group.

Effect of ERW on the expression of $A D H$ and $A L D H$ The relative expression of ADH1 in serum of the ERW-treated group was increased by about 3.3-fold compared with that in the Con group $(P<0.01)$. In addition, the expression of ALDH of the Exp group increased by approximately 3.5 -fold compared with the Con group $(P<0.05)$ (Fig. 1).

Effect of ERW on the levels of liver marker enzymes (ALT, AST, ALP and GGT)

Oral administration of ERW led to a significant reduction of AST level in the Exp group (117.1 \pm $8.005 \mathrm{U} / \mathrm{L})$ compared with the Con group $(173.2 \pm$ $29.15 \mathrm{U} / \mathrm{L})(P<0.05)$. ALT level was also slightly decreased in the Exp group $(35.13 \pm 2.467 \mathrm{U} / \mathrm{L})$ compared to the Con group $(42.17 \pm 6.215 \mathrm{U} / \mathrm{L})$,

Table 1 Serum alcohol concentration in rats treated with $40 \%$ ethanol

\begin{tabular}{ccc}
\hline & \multicolumn{2}{c}{ Serum alcohol concentration $(\mathrm{mM})$} \\
\cline { 2 - 3 } Time & Control group & Experimental group \\
\hline $1 \mathrm{~h}$ & $89.70 \pm 19.172$ & $40.67 \pm 3.865^{*}$ \\
$3 \mathrm{~h}$ & $81.98 \pm 17.454$ & $33.61 \pm 3.564^{*}$ \\
$5 \mathrm{~h}$ & $68.42 \pm 9.420$ & $32.77 \pm 2.946^{* *}$ \\
\hline
\end{tabular}

Values are expressed as mean \pm SD for 10 rats in each group. $* P<0.05$ vs. control group, ${ }^{* *} P<0.01$ vs. control group

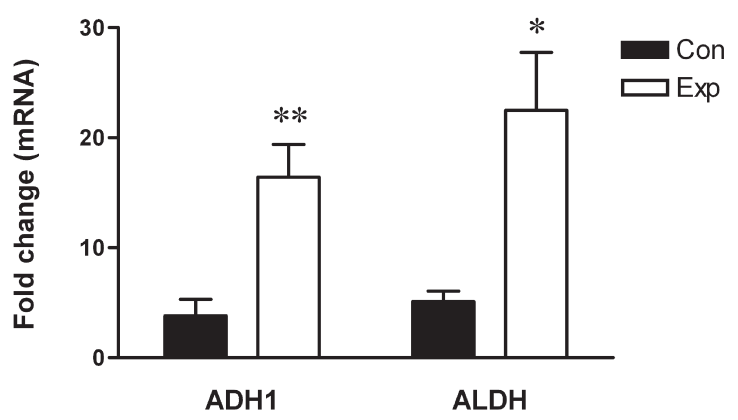

Fig. 1 The mRNA expression levels of alcohol dehydrogenase1 $(A D H 1)$ and acetaldehyde dehydrogenase (ALDH) in liver tissue $24 \mathrm{~h}$ after administration with $40 \%$ ethanol by quantitative real-time PCR. Values represent mean \pm SD $(n=10)$. Exp: ERW-treated group, Con: DW-treated group, ${ }^{*} P<0.05,{ }^{*} P<0.01$ although there was no statistical significance. However, ALP and GGT levels did not show any differences between two groups (Fig. 2).

\section{Effect of ERW on GSH, GPx and GST in liver}

The GSH level of the Exp group $(2397 \pm 145.9 \mu \mathrm{M})$ was significantly increased $24 \mathrm{~h}$ after ERW and $40 \%$ ethanol administration orally when compared with the control group $(1807 \pm 185.1 \mu \mathrm{M})(P<0.05)$ (Fig. 3). Pre-oral administration of ERW significantly increased hepatic GPx activity $(1655 \pm 226.6 \mathrm{nmol} /$ $\mathrm{min} / \mathrm{mL}$ ) compared to the control group (817.6 \pm $158.1 \mathrm{nmol} / \mathrm{min} / \mathrm{mL}) 24 \mathrm{~h}$ after treatment with ethanol $(P<0.05)$ (Fig. 4). On the other hand, as shown in Fig. 4, the activity of GST in the ERW treated
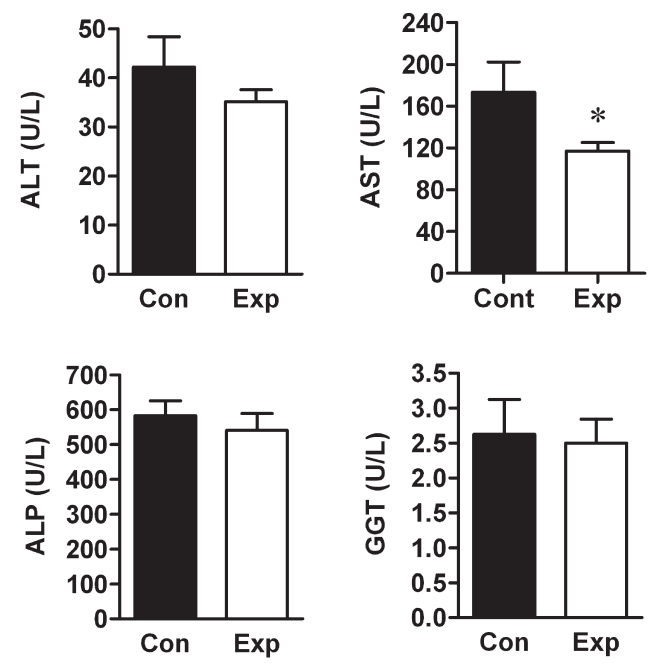

Fig. 2 The level of liver marker enzymes (ALT, AST, ALP, and GGT) in the serum $24 \mathrm{~h}$ after $40 \%$ ethanol treatment. Values represent mean $\pm S D(n=10)$. ALT: alanine aminotransferase, AST: aspartate aminotransferase, ALP: alkaline phosphatase, and GGT: gamma glutamyl transpeptidase, Exp: ERW-treated group, Con: DW-treated group, ${ }^{*} P<0.05$

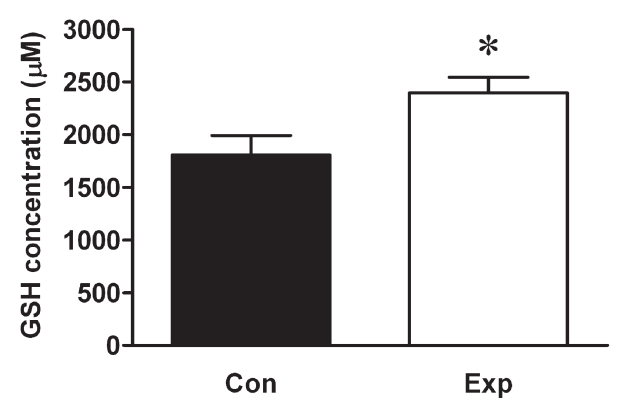

Fig. 3 Glutathione (GSH) concentration in liver tissue of rats $24 \mathrm{~h}$ after $40 \%$ ethanol. Values represent mean $\pm \mathrm{SD}$ $(n=10)$. Exp: ERW-treated group, Con: DW-treated group, ${ }^{*} P<0.05$ 
experimental group $(1984 \pm 323.5 \mathrm{nmol} / \mathrm{min} / \mathrm{mL})$ was increased by approximately $50 \%$ compared to the control group $(987.6 \pm 268.2 \mathrm{nmol} / \mathrm{min} / \mathrm{mL})$ $(P<0.05)$.

\section{Effect of ERW on the expression of Cu/Zn-SOD and} CAT

The activities of $\mathrm{Cu} / \mathrm{Zn}$-SOD and CAT were analyzed by measuring the mRNA expression levels of these enzymes in liver tissue by quantitative realtime PCR. The mRNA expression levels of $\mathrm{Cu} / \mathrm{Zn}$ SOD was increased by approximately 3.1 -fold in the ERW-treated group compared to the Con group $(P<0.05)$. Similarly, CAT mRNA expression levels were also significantly higher in the Exp group than that in the Con group $(P<0.05)$ (Fig. 5).

\section{DISCUSSION}

Hangovers are induced by ethanol and its metabo-

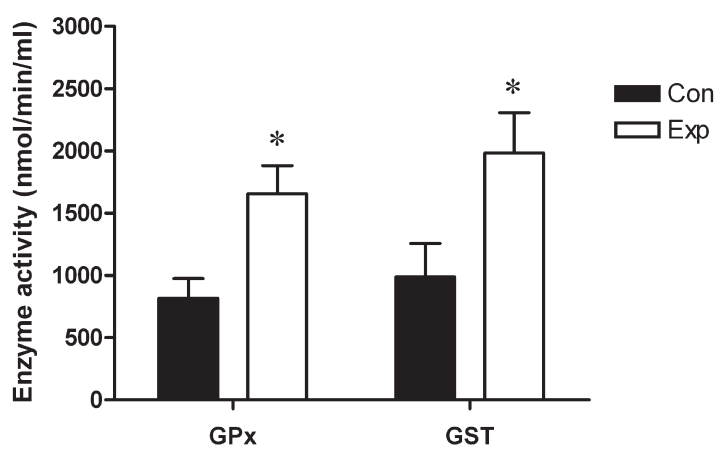

Fig. 4 The activities of glutathione peroxidase (GPx) and glutathione S-Transferase (GST) in liver tissue of rats $24 \mathrm{~h}$ after $40 \%$ ethanol treatment by quantitative real-time PCR. Values represent mean $\pm S D(n=10)$. Exp: ERW-treated group, Con: DW-treated group, ${ }^{*} P<0.05$

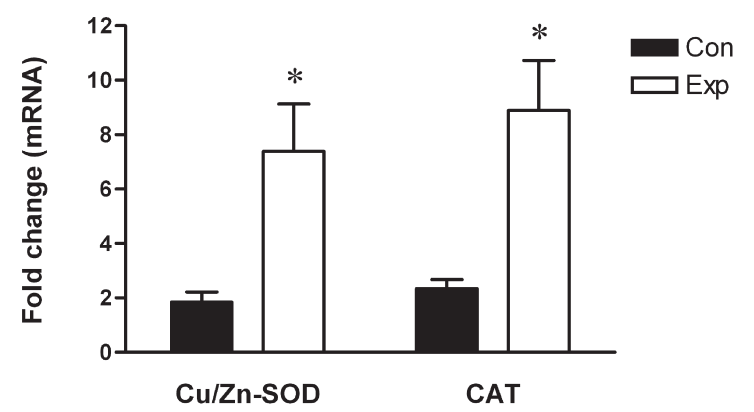

Fig. 5 The mRNA expression of $\mathrm{Cu} / \mathrm{Zn}$-superoxide dismutase (Cu/Zn-SOD) and catalase (CAT) in liver tissue of rats $24 \mathrm{~h}$ after $40 \%$ ethanol treatment by quantitative realtime PCR. Values represent mean \pm SD $(n=10)$. Exp: ERWtreated group, Con: DW-treated group, ${ }^{*} P<0.05$ lites such as acetaldehyde and acetate (3). Therefore, ethanol metabolism in the liver is involved in recovery of hangover. It is known that ethanol is oxidized to acetaldehyde and acetate by $\mathrm{ADH}$ and ALDH. These enzymes are directly related with ethanol metabolism $(4,14)$. The activities of ADH and ALDH have been shown to be greatly reduced in liver tissue of ethanol-loaded mice (3). In this study, relative expression of ADH and ALDH in the ERWadministered group was significantly increased $24 \mathrm{~h}$ after $40 \%$ ethanol intake compared with the control group administrated with distilled water (Fig. 1). Increased $\mathrm{ADH}$ and $\mathrm{ALDH}$ expression explains the result that serum alcohol concentration of the ERWadministrated group was significantly lower than that of control group at $1 \mathrm{~h}, 3 \mathrm{~h}$ and $5 \mathrm{~h}$ after alcohol intake (Table 1).

We further explored the potential mechanism involved in the inhibition of ethanol-induced hangovers by ERW. Heavy intake of ethanol disturbs the delicate balance between the pro- and anti-oxidant systems of the organism, therefore leading to oxidative stress (26). Elevated generation of reactive oxygen species (ROS) or free radicals causes autooxidation of hepatic cells, resulting in marked hepatic lesions (21), therefore inducing leakage of cellular enzymes into the serum (2). Kumar Rajagopal et al. (11) demonstrated that serum levels of AST or ALT increased in ethanol-administered rats by damage of both hepatic cellular and mitochondrial membranes. The increased activities of liver marker enzymes such as ALT, AST, ALP, and GGT have previously been detected in alcoholadministered mice $(13,16)$, implying the increased permeability, damage and necrosis of hepatocytes. However, in this study, the levels of ALT and AST, but not those of ALP and GGT, were decreased by pre-administration of ERW compared with control group $24 \mathrm{~h}$ after $40 \%$ ethanol oral-administration. This indicates that ERW could induce some mechanism to preserve the structural integrity of liver cells and hepatic mitochondria from the adverse effects of ethanol.

The potential harmful effects of ROS and/or free radicals are controlled by the cellular antioxidant defense system (22). The inhibition of the antioxidant system may cause the accumulation of $\mathrm{H}_{2} \mathrm{O}_{2}$ or products of its decomposition (5). Enzymatic antioxidants such as SOD, CAT, GPx and GST are the first line of defense against oxidative injury. SOD and CAT are the enzymes that help to scavenge superoxide ions and hydroxyl ions respectively. It is known that the activities of SOD and CAT are sig- 
nificantly decreased in ethanol-administered mice (3, $13,16,18)$. On the other hand, GPx and GST play a crucial role in scavenging ROS and/or free radicals, and acute or chronic ethanol oral administration causes a decrease in the activities of GPx and GST in liver tissue of rats $(3,15,16,18)$. Ethanol or its metabolites might specifically target GST isoenzymes, and the reduction in enzyme activity or expression may contribute to ethanol hepatotoxicity (16). In addition, GSH (the major non-enzymatic antioxidant) plays a central role in coordinating the antioxidant defense processes, which is involved in the maintenance of normal cell structure and function because of its involvement in redox and detoxification reactions (17). In the present study, the oral administration of ERW showed to increase the concentration and activities of several non-enzymatic and enzymatic antioxidants such as GSH, GPx, GST, SOD, and CAT in liver tissue of rats $24 \mathrm{~h}$ after $40 \%$ ethanol intake. This result indicates that ERW potentially has a positive effect on the alcohol metabolism through the elevation of antioxidant-related enzyme activity.

ERW produced by electrolysis from tap water has the properties of a high $\mathrm{pH}(9.0-10.0)$, significantly low oxidation reduction potential (ORP) values, low dissolved oxygen (DO) and high dissolved hydrogen (DH) compared to non-electrolyzed water. According to other researchers, ERW exhibits various bioactive functions. Jin et al. (9) and Kim et al. (10) demonstrated anti-diabetic effect of ERW through the results of reduced blood glucose concentration, increased blood insulin level, improved glucose tolerance and preserved pancreatic $\beta$-cell mass using diabetic animal model. Huang et al. $(7,8)$ demonstrated the potential therapeutic effects of ERW through reduction of hemodialysis-induced oxidative stress and erythrocyte impairment in end-stage renal disease patients. ERW also has a tendency to suppress single-strand breakage of DNA induced by ROS in vitro (19) and selectively stimulates the growth of anaerobic microflora in the human intestinal tract (23). The mechanism of these researches has been partly explained by anti-oxidant effect of ERW and reduced oxidative stress. Recent increasing evidences suggest that ERW has an antioxidant effect by scavenging ROS or free radicals including superoxide anion radicals $\left(\mathrm{O}_{2}^{-} \cdot\right)$, hydrogen peroxide molecules $\left(\mathrm{H}_{2} \mathrm{O}_{2}\right)$, singlet oxygen $\left({ }^{\mathrm{I}} \mathrm{O}_{2}\right)$ and hydroxyl radicals $(\cdot \mathrm{OH})(20,25)$. Moreover Hanaoka et al. (6) reported that the enhancement of antioxidant effects of ERW was due to the increase of the ionic product of water $\left(\mathrm{p} K_{\mathrm{w}}\right)$ as solvent, therefore enhancing the superoxide anion radical dismutation activity in ERW. ERW also exhibits strong and stable SODand CAT-like activities because of extremely high concentration of dissolved molecular hydrogen (DH) produced in ERW during electrolysis of water (19). On the basis of these mechanisms, oral administration of ERW is supposed to elicit detoxification effect against alcohol-induced toxicity as seen from the lower level of liver marker enzymes in serum and higher expression of antioxidant enzymes in liver tissue in the SD rats treated with $40 \%$ ethanol.

In conclusion, pre-oral administration of ERW was more effective in increasing ADH and ALDH expression in liver tissue $24 \mathrm{~h}$ after ethanol administration and in reducing alcohol concentration in serum at $1 \mathrm{~h}, 3 \mathrm{~h}$ and $5 \mathrm{~h}$ compared with DW-treated control group. In addition, it decreased the activity of liver marker enzymes in serum (AST and ALT) and antioxidant enzymes in liver tissue (GPx, GST, $\mathrm{Cu} / \mathrm{Zn}$-SOD and CAT) compared with control group. These results indicate that ERW protects anti-oxidative system from excess ROS and/or free radicals induced by ethanol administration, and enhances ethanol detoxification by increase in the activities of enzymes related to the alcohol metabolism in vivo. Hence it is considered that drinking ERW has a potential relieving effect in acute ethanol-induced hangovers.

\section{REFERENCES}

1. Alatalo P, Koivisto H, Puukka K, Hietala J, Anttila P, Bloigu R and Niemelä O (2009) Biomarkers of liver status in heavy drinkers, moderate drinkers and abstainers. Alcohol Alcoholism 44, 199-203.

2. Baldi E, Burra P, Plebani M and Salvagnini M (1993) Serum malondialdehyde and mitochondrial aspartate aminotransferase activity as markers of chronic alcohol intake and alcoholic liver disease. Ital J Gastroenterol 25, 429-432.

3. Cho MH, Shim SM, Lee SR, Mar W and Kim GH (2005) Effect of Evodiae Fructus extracts on gene expressions related with alcohol metabolism and antioxidation in ethanolloaded mice. Food Chem Toxicol 43, 1365-1371.

4. Gill K, Amit Z and Smith BR (1996) The regulation of alcohol consumption in rats: the role of alcohol-metabolizing enzymes-catalase and aldehyde dehydrogenase. Alcohol 13, 347-353.

5. Halliwell B (1994) Free radicals, antioxidants, and human disease: curiosity, cause, or consequence? Lancet 344, 721724.

6. Hanaoka K, Sun D, Lawrence R, Kamitani Y and Fernandes G (2004) The mechanism of the enhanced antioxidant effects against superoxide anion radicals of reduced water produced by electrolysis. Biophys Chem 107, 71-82.

7. Huang KC, Yang CC, Hsu SP, Lee KT, Liu HW, Morisawa S, Otsubo K and Chien CT (2006) Electrolyzed-reduced water reduced hemodialysis-induced erythrocyte impairment in endstage renal disease patients. Kidney Int 70, 391-398. 
8. Huang KC, Yang CC, Lee KT and Chien CT (2003) Reduced hemodialysis-induced oxidative stress in end-stage renal disease patients by electrolyzed reduced water. Kidney Int 64, 704-714.

9. Jin D, Ryu SH, Kim HW, Yang EJ, Lim SJ, Ryang YS, Chung CH, Park SK and Lee KJ (2006) Anti-diabetic effect of alkaline-reduced water on OLETF rats. Biosci Biotechnol Biochem 70, 31-37.

10. Kim MJ and Kim HK (2006) Anti-diabetic effects of electrolyzed reduced water in streptozotocin-induced and genetic diabetic mice. Life Sci 79, 2288-2292.

11. Kumar Rajagopal S, Manickam P, Periyasamy V and Namasivayam N (2003) Activity of Cassia auriculata leaf extract in rats with alcoholic liver injury. $J$ Nutr Biochem 14, 452-458.

12. Leon DA and McCambridge J (2006) Liver cirrhosis mortality rates in Britain from 1950 to 2002: an analysis of routine data. Lancet 367, 52-56.

13. Li YG, Ji DF, Chen S and Hu GY (2008) Protective effects of sericin protein on alcohol-mediated liver damage in mice. Alcohol Alcoholism 43, 246-253.

14. Lieber CS (1985) Alcohol and the liver: metabolism of ethanol, metabolic effects and pathogenesis of injury. Acta Med Scand Suppl 703,11-55.

15. Lieber CS (1995) Medical disorders of alcoholism. $N$ Engl $J$ Med 333, 1058-1065.

16. Pari L and Suresh A (2008) Effect of grape (Vitis vinifera L.) leaf extract on alcohol induced oxidative stress in rats. Food Chem Toxicol 46, 1627-1634.

17. Pshezhetsky AV, Danilova RA, Fedorova IM, Sagimbaeva SK, Pervushina SV, Obuchova MA, Svedas VK and Ashmarin IP (1993) Influence of the immunization against heterologous alcohol dehydrogenase on liver alcohol dehydrogenase iso- zymes and alcohol abuse of rats. Eur $J$ Biochem 212, 757761.

18. Saravanan N and Nalini N (2007) Antioxidant effect of Hemidesmus indicus on ethanol-induced hepatotoxicity in rats. J Med Food 10, 675-682.

19. Shirahata S, Kabayama S, Nakano M, Miura T, Kusumoto K, Gotoh M, Hayashi H, Otsubo K, Morisawa S and Katakura Y (1997) Electrolyzed-reduced water scavenges active oxygen species and protects DNA from oxidative damage. Biochem Biophys Res Commun 234, 269-274.

20. Sillanaukee P (1996) Laboratory markers of alcohol abuse. Alcohol Alcohol 31, 613-616.

21. Suzuki Y, Ishihara M, Segami T and Ito M (1998) Anti-ulcer effects of antioxidants, quercetin, alpha-tocopherol, nifedipine and tetracycline in rats. Jpn J Pharmacol 78, 435-441.

22. Thampi BS, Manoj G, Leelamma S and Menon VP (1991) Dietary fiber and lipid peroxidation: effect of dietary fiber on levels of lipids and lipid peroxides in high fat diet. Indian $J$ Exp Biol 29, 563-567.

23. Vorobjeva NV (2005) Selective stimulation of the growth of anaerobic microflora in the human intestinal tract by electrolyzed reducing water. Med Hypotheses 64, 543-546.

24. Watanabe T (1995) Effect of alkaline ionized water on reproduction in gestational and lactational rats. J Toxicol Sci 20, 135-142.

25. Yanagihara T, Arai K, Miyamae K, Sato B, Shudo T, Yamada M and Aoyama M (2005) Electrolyzed hydrogen-saturated water for drinking use elicits an antioxidative effect: a feeding test with rats. Biosci Biotechnol Biochem 69, 1985-1987.

26. Zima T, Fialova L, Mestek O, Janebova M, Crkovska J, Malbohan I, Stipek S, Mikulikova L and Popov P (2001) Oxidative stress, metabolism of ethanol and alcohol-related diseases. J Biomed Sci 8, 59-70. 
